\title{
Social Entrepreneurship: A Panacea for Correcting Economic Growth and Development Paradoxes in Less Developing Countries - A Case of Nigerian Economy
}

\author{
Anietie E. Efi (Ph.D) \\ Director, Center for Entrepreneurial Development \\ Faculty of Business Administration, University of Uyo, Uyo, Nigeria \\ Email of corresponding Author: efianietie@gmail.com
}

\section{Etim, E. Osim (Aca)}

Department of Accounting

University of Uyo, Uyo, Nigeria

\author{
Doi:10.5901/ajis.2014.v3n4p485
}

\begin{abstract}
The purpose of the paper is to examine how development of social entrepreneurship can redress the abnormalities associated with economic growth and development paradox. This is because rapid economic growth and various experiments with activist government have not been sufficient to lift a huge portion of the world population, particularly those of less developed countries (LDCs) out of poverty. EX-post facto research was adopted for the study involving review of economic growth and development plans of the country from independence to date, and a comparative analysis of select oil producing countries and Asian countries socio-economic indices. These select countries were decades back rated at par with Nigeria, but today have left the country behind. Data were presented on tables and simple percentage (\%) used for simplified comparison and inferences. Results shows poor social-economic indices for the country over the past decades compared to other select countries. It was therefore concluded that articulation of policies that can impact on the well-being of the populace should integrate socialentrepreneurship programmes and policies to promote self-reliance and productive activities at individual and community-levels so that their attendant chain-effects can revamp the economy and restore human dignity.
\end{abstract}

Keywords: Social Entrepreneur, poverty, self-reliance, economic growth and development.

\section{Introduction}

For several years during the $20^{\text {th }}$ century, governments in less developed countries (LDCs) witnessed considerable changes in their roles as assigned by economist from time to time. Up to the end of the second war world, the state was assigned limited role in terms of involvement in economic activities. At independence, several countries attained the commanding height of the economy in the public sector. The government focus on frameworks for stabilization of the economy through diverse micro and macro economic polices. The frameworks could not achieve conducive macro economic environment, poverty reduction, economic growth, full employment, infrastructural development, research and development (R\&D) among others. In general, the overall objective of public expenditure to improve social welfare and the performance of private commercial sector remain elusive. With the resultant macroeconomic imbalances, unemployment sour to it highest in the past few decade, couple with debt crises that plagued several of the developing economies. Many of the tested policies of International Development Agencies such as Structural Adjustment Programme (SAP), Accelerate Development Programme (ADP), Integrated Rural Development Programe (IRDP), turned out to be active-poor rather than anti-poverty, that is lacking a human face. In developing countries, like Nigeria, consequently, economic growth and development indices move at opposite direction giving the growth-development paradox. That is, economic growth and development plans of developing nations not been in tandem with realities to drive the economy to robustness and thus improve socio-economic indices.

To avoid the merry-go-round of programme and plans without proper implementation and activities and actions without progress, comes the need to critically assess strategic economic development plans visa-vis social entrepreneurship, to see what can be learned from those that have moved ahead through this medium (social entrepreneurship) as the nations strive to develop. There may be an urgent need to provide the required enabling environment for the development of social entrepreneurship, so that they could adequately play their role in economic 
transformation agenda. Such roles includes mobilization of domestic savings for investment, appreciable contribution to gross domestic product, increased harnessing of local raw materials, employment generation, significant contribution of poverty reduction efforts through sustainable livelihoods and enhancement in personal income, technological development and export diversification.

Dees (2007) observe that "Rapid economic growth and various experiments with activist governments have not been sufficient to lift a huge portion of the world population out of poverty, curable and preventable diseases still cause tremendous suffering and claim many lives particularly among the poor..."

These assertions show therefore that something still need to be done which has not been done or which has been done but not done properly.

This study therefore seek to explain how these anomalies can be overcome through active development of social entrepreneurship initiatives in developing economics using the Nigerian economy as a focus-a country with economic growth without development paradox.

\section{Statement of the Problem}

One common strand gleaned from happenings around the world particularly among less developed countries is the failure of organized for-profit business in social responsibility, as well as the public sector failure to respond to social-economic problems. This is not unconnected with the current emphasis on individualism occasioned by capitalism, that has prized profiteering over the virtue of contribution to public good. Drayton (2002) corroborates the inordinate profiteering tendencies of business owners, which are antithetical to public good. Profiles of corporate heroes have given way to cautionary tales about greedy villains, and public trust in business has plummeted. This trend has, therefore, called for the need to have a new approach that is sensitive to the needs of the people, particularly the poor. Hence, the need to study how social entrepreneurship may be a panacea to resolving the economic growth and development paradoxes in less developed economies.

\subsection{Objectives of the Study}

The main objective of this study is to examine how development of social entrepreneurship can be use to address the abnormality of economic growth without development in Nigeria (correction of the paradox of growth without development).

Other subsidiary objectives include:

i. To examine causes of growth without development paradox in Nigeria.

ii. To evaluate the economic planning profile of Nigeria over the years that has not yielded positive socioeconomic robustness.

\subsection{Research Questions}

The following research questions are developed for the study:

i. What are the causes of economic growth without development in Nigeria?

ii. Why has economic planning policies of Nigeria over the years not yielded positive socio-economic robustness?

Answers to these questions, will address the formulation of possible policy measures aim at strengthening the development of social entrepreneurship as a media for correcting socio-economic problems that has not been addressed by lofty micro and macro economic policies of developing nations, such as Nigeria.

\section{Review of Relevant Literature}

Most studies conducted over the years on economic growth and development paradoxes or macro economic imbalances often focus on diversification of economies with particular attention to industrialization and reforms in the financial services sector. Many of the studies have indicated that the revival of interest in SMEs (for which social entrepreneurships is a sub-set) in the developed economies is due to technological as well as social reasons, namely, the growing importance of knowledge and skill-based industry as against material and energy-intensive industry. This is also due to a paradigm shift to new processes of manufacturing based on flexible systems of production. The social reasons 
include the need for generation of more employment through self-employment ventures and decentralized work centers (Udechukwu, 2009).

The conditions that brought about the emergence and enthusiasm on social entrepreneurship were not unconnected with the failure of organized for profit business in social responsibility (Dees et al 2004).

Dees (2007) identifies some distinct advantages social entrepreneurship practitioners have over government following the myriad of problems facing the world which has called for action and collaborations between the government and the institution of social entrepreneurship. These advantages include:

- They have greater freedom of action and can usually move more quickly than government officials.

- They can employ a wide range of alternative largely because they are not constrained by bureaucratic rules, legislative mandates, political considerations, and a fixed budget.

- Flexibility of action in that they can tailor their efforts to different communities or markets in ways that would be difficult for government programmes and

- Social entrepreneur have access to private resources, while private contributions to government are relatively rare.

Thus, apart from dearth of resources on the part of governments, social entrepreneurship offers the above advantages.

Nigeria over the years, has embark upon various economic growth and development plans reviewed under three main dispensations via:

i. Central planning through medium term development plan (1960-1985).

ii. Structural adjustment policy regime (1986-1990), and

iii. Economic reforms through poverty reduction strategic plans (1999-date), all a view to correcting macro economic imbalances. These are reviewed below:

\subsection{Central Management of the Economy through Medium Term Development Plans}

According to Onodugo (2013), Nigerian development plans between 1960-1985 saw four main plans: 1st development plan (1962-1985) developed to accelerate the growth of the economy by targeting agriculture, industrial and manpower development; 2nd development plan (1970-74): This plan aimed at reconstruction of infrastructures damaged during the war and indigenization programme; 3rd development plan (1975-1980) at sustaining growth during the time of oil boom, 4th development plan (1981-1985) aimed at economic stabilization/austerity measures following oil glut.

The challenges with central planning regime were that:

- There was no participation from the citizenry.

- Most of the projections were not anchored on reliable data.

- It was foisted on the citizens, with neglect of the private sector.

- There was no continuity among regimes; and

- Wasteful spending from boom as well as absence of long run vision to guide the plan (Onodugo, 2013, Ndiyo, 2010).

\subsection{Structural Adjustment Policy Regime 1986-1990}

This strategic plan came on the heels of austerity measures of the early 1990s. The essential thrust of SAP was to disengage government from economic activity as well as from their role as providers of social services and creating a more market-friendly environment underpinned by measures and incentives that would encourage private enterprise and more efficient allocation of resources. The policy thrust failed because it exacerbate income inequality as well as absence of the necessary socio-economic and political institutional framework to fast track the assimilations of its benefits (Etim, 2010).

\subsection{Economic Reforms Using Poverty Reduction Strategy Plan (Prsp) (1999-Date)}

This regime comprises - National Economic Empowerment Development Strategy (NEEDs) 7-point Agenda, Transformation Agenda and Vision 2020 (Ebimobowel, 2010) Khorravi and Karimi, 2010). This policy regime witnesses the introduction of series of reforms that were aimed at redressing the distortions in the economy and to restore economic growth after the economy almost disappeared under the previous regimes. Economic management approach under this 
epoch made use of PRSP to guide the economy away from public sector led economy to private sector driven economy.

The major challenges of economic development under PRSP were that:

- Lack of continuity and confusing targets among programmes.

- Absence of machinery to implements and monitor implementation.

- Policy still driven by the elite and far from being pro-poor.

- Corruption and policy reversals.

Gerald Meier, a famous development economist, in Ndiyo (2010), once noted the dissatisfaction felt by many people over the results of development during the past three decades. Such discontent, bordering on bewilderment reached the doors of the world Bank and other international organizations like the EC, UNDP, etc. These failure in economic growth and development policies particularly among less developed countries has kept over 40 percent of the people in absolute poverty (Ogwumike, 1998; Fukuyama, 1995; Granovetter, 1985; Archibong, 1997; Aigbokhan 1998; Ajakaiye and Adeyeye, 2001; Anyanwu, 1997); Obadan (1997); World Bank (1990, 1995-1996); and many other empirical studies on Nigeria socio-economic problems identified several causes or combination of several complex factors. These include among others inappropriate macro-economic policies, crowding out in the labour market resulting from limited job growth, low productivity and low wages in the informal sector, and a lag in human resource development. This leads us to next phase of the study involving data comparison and analysis.

\section{Methodology}

The study involves achieval studies and ex-post factor research to examine extant literature on why the Nigerian economy is growing yet no development. Data for analysis are extracted from publications of regulatory agencies such as the Central Bank of Nigeria (CBN), National Bureau of statistics (NBS) as well as other relevant international agencies reports. Although, no robust statistical technique is adopted, inferences drawn from the data giving their reliability is justifiable for informed policy recommendations.

\section{Results and Discussion}

Nigeria has experimented various options of strategic economic planning - central planning, structural adjustment, home growth reforms (NEEDS, transformation Agenda, and vision 20:2020). The results after three decades of planning leave us with only paradoxes as shown below:

Table 4.1: Socio - Economic indices

\begin{tabular}{|l|l|}
\hline Economic growth & $6.5 \%$ Average per annum \\
\hline Unemployment & $23 \%-25 \%$ Average \\
\hline Poverty index & 112.5 million (69\%) live below poverty line \\
\hline Core-Export commodity & Driven by sale of crude oil and unprocessed primary products \\
\hline Import variables & Refined petroleum products and all sorts of manufactured products \\
\hline
\end{tabular}

Source: NBS, 2012, CBN Report various issues

From the extract above, the Nigeria economy has not fare well when compared to global index or bench mark. The indices clearly shows that a greater number of the population accounting for $69 \%$ live below poverty lines and unemployment rate of $23 \%-25 \%$ are wallowing in poverty. There is lack of coherent policy linking the primary agricultural sector with the industrial sector. There is also a de-link between the real sectors and the financial services sector which has led to various reforms, yet no substantial changes or improvement.

A further review of the Nigeria economy at a glance indicates the following results. 
Table 4.2: Nigeria Economy at a glance

\begin{tabular}{|l|l|}
\hline Variables & Index as at 2013 figures \\
\hline Population & $168,833,770$ \\
\hline GDP & $\$ 262,605,908,770$ \\
\hline Consumer Price index (CPI) & Averaged 94.18 index point \\
\hline Interest rate & $12 \%$ Average \\
\hline Reserves & $\$ 48$ billion \\
\hline FDI Inflow & $\$ 800 \mathrm{bn}$ \\
\hline Power supply & $4500 \mathrm{mw}$ as at 2013 \\
\hline Growth rate & $6.8 \%$ Average between $2005-2013$ \\
\hline
\end{tabular}

Source: CBN Reports (various issues)

At a glance, it can be deduced that something is wrong with the structure of Nigeria economy that is growing without poverty reduction. The major driver of this growth is the oil and gas sector that employs only about $1 \%$ of the population ( $95 \%$ of export earning and $80 \%$ of GDP). Also, the economy is polarized with many very poor people amidst few that are very rick. Agricultural and manufacturing sectors that are capable of affecting more than $70 \%$ of the population is left idle or comatose. These scenarios results in economic growth without development.

\subsection{A Comparative Indices of Nigerian Economic Index with Other Selected Countries}

For a better inference of the performance of Nigeria economy, a comparative analysis of the economy with that of some other selected oil producing nations - Venezuela and Saudi Arabia is presented on table 4.3 below.

\begin{tabular}{|c|c|c|c|c|c|}
\hline Country/year & Oil production position & GDP per capital (US\$) & $\begin{array}{c}\text { Unemployed } \\
\text { Rate }\end{array}$ & $\begin{array}{c}\text { Human Development } \\
\text { Index }\end{array}$ & Literary Ranking \\
\hline Nigeria & 11 & 1432 & 21.1 & 0.462 & - \\
2010 & 11 & 1486 & 23.9 & 0.467 & - \\
2011 & 11 & 1555 & - & 0.471 & 170 \\
2012 & 12 & 13559 & & & - \\
\hline Venezuela & 12 & 10728 & 8.6 & 0.744 & - \\
2010 & 12 & 12767 & 8.0 & 0.746 & 100 \\
2011 & 2 & 16538 & 10.0 & 0.749 & - \\
2012 & 20778 & - & 0.777 & - \\
\hline Saudi Arabia & 2 & - & - & 10.782 & 154 \\
2010 & 2 & & \\
2011 & 2 & &
\end{tabular}

Source: World Bank Statistical Tables and UNESCO Tables (Various Issues)

Nigeria rank $11^{\text {th }}$ in global oil production index compared to Venezuela and Saudi Arabia which rank $12^{\text {th }}$ and $2^{\text {nd }}$ respectively; the GDP (US \$) is merely 1491 average compared to 12351 and 18808 for the other two countries; the Human Development Index (HDI) for Nigeria was a mere 0.462 compared with Venezuela 0.744 and Saudi Arabia 0.777; and by 2012 the statistics were $0.471,0.749$ and 0.782 respectively.

In the 2012 literacy level ranking worldwide, while Venezuela ranked $100^{\text {th }}$, Saudi Arabia 154th, Nigeria ranked 170th.

Moreso, there is the crucial challenge of poor Human Development Index (HDI), life expectancy and mean years of schooling for Nigeria vis-à-vis some Asian countries as shown below: 
Table 4.4: Performance of Nigeria vis-a-vis Asia countries on HDI (1980-2011)

\begin{tabular}{|c|c|c|c|c|c|c|}
\hline HDI & Country & $\begin{array}{c}\text { HDI } \\
\mathbf{2 0 1 1 )}\end{array}$ & $\begin{array}{c}\text { HDI } \\
(\mathbf{1 9 8 0 )}\end{array}$ & $\begin{array}{c}\text { HDI\% } \\
(\mathbf{1 9 8 0 - 2 0 1 1 )}\end{array}$ & $\begin{array}{c}\text { Life } \\
\text { Expec-tancy }\end{array}$ & $\begin{array}{c}\text { Mean years } \\
\text { of schooling }\end{array}$ \\
\hline 101 & China & 0.687 & 0.404 & $70.0 \%$ & 73.5 & 7.5 \\
134 & India & 0.547 & 0.344 & $59 \%$ & 65.4 & 4.4 \\
156 & Nigeria & 0.467 & NIA & NA & 51.9 & 5.0 \\
103 & Thailand & 0.682 & 0.486 & $40.3 \%$ & 74.1 & 6.6 \\
124 & Indonesia & 0.617 & 0.423 & $45.9 \%$ & 69.4 & 5.8 \\
\hline
\end{tabular}

Source: World Bank Statistical Tables and Unesco Tables (Various issue)

The above analysis is premise on the fact these selected countries a few decades back were at par with Nigeria in virtually every aspect of economic, political and social indices. But as presented above, these countries have left us behind.

Taking a queque of what governments of Malaysia, Philippine, Mauritius, Pakistan, India, South Korea, North Korea, Thailand and many of the newly Industrialized countries (NICs) did, policies and programmes that integrate social entrepreneurship and Domestic Small and Medium Enterprises (SMEs), into the mainstream of macro economic and industrial development plans; through the provision of critical inputs that enable them to expand their social responsibilities and markets internationally, championing new openings in the export markets for the products and services of entrepreneurship, devotion of lending portfolios to micro, cottage, small and medium enterprises as well as close government-private sector initiative that made this sub-sector to account for over 80.0 percent of total employment and contribute not less than 30.0 percent to GDP, annually.

In Nigeria, as in any other less developing countries, since the organized manufacturing sector is made up of over $95 \%$ SMEs and by extension social entrepreneurs, there is therefore, more than ever before, the need to fine tune SMEs policies and align them with other development strategies so that the economy could revamp as is obtainable among the Asian nations.

Optimizing the full benefits of social entrepreneurship in less developed countries, the governments should embark on policies that encourages fiscal incentives, infrastructure development, strengthening of rural access to financial services, and incorporation of entrepreneur programmes to educational studies aim at emphasizing self-reliance and personal development.

\section{Concluding Remarks}

Undoubtedly, the articulation of policies that will impact on socio-economic well-being of vast majority of the populace in less developed countries requires integrating social entrepreneur issues into the main fabrics of economic planning framework. This is with a view to enhancing the growth factors of GDP and other life enhancement indictors, thereby lifting the majority of citizenry from poverty level to sustainable development levels. It is pertinent therefore; that LDCs formulate and implement policies and programmes to emphasize self-reliance development so as to promote productive activities with their attendant chain effects of boosting virtually all sectors of the economy.

Though, the government and other international economic development agencies have implemented some projects geared towards minimizing poverty and other poor social-economic indices, their poor implementation, and, a revisit and fine-tuning of these programmes in lines with social entrepreneurship to keep pace. With current realities and global best practices is being advocated. There and then, the Nigerian economy as well as other LDCs could revamp and robust to restore the dignity of human existence.

\section{References}

Aigbokhan, B. E. (1998). Poverty, Growth and Inequality in Nigeria: A Case Study, Final Report Presented at the AERC Workshop, Nairobi, Kenya.

Ajakaiye, D. O. and V. A. Adeyeye (2001). "The Nature of Poverty in Nigeria", Technical Report, NISER, Ibadan.

Anyanwu, J. C. (1997). "Poverty: Concepts, Measurement and Determinants", Proceedings of NES Conference on Poverty Alleviation in Nigeria, University of Ibadan, Ibadan.

Archibong, P. E. (1997). "Nigeria: Towards a Realistic and Integrated Anti-poverty Strategy", In: Poverty Alleviation in Nigeria; Selected Papers for the Annual Conference of Nigerian Economic Society. 
Central Bank of Nigeria (CBN) (Various years), Annual Reports and Statistics, Lagos and Abuja.

Central Bank of Nigeria (CBN) (various years), Annual Reports and Statistics, Lagos and Abuja.

Central Basic of Nigeria (CBN) (1999). Nigeria's Development Prospects; Poverty Assessment and Alleviation Study, Research Department, Abuja.

Dees, J. G. (2007). Taking social entrepreneurship seriously. Society vol. 44 No. 1 Harvard Business Review.

Dees, J. G. B. B. Anderson, and Jane Welskillern (2004). Standford Social innovation Review, Spring 2004. Earlier Working paper version available from CASE.

Drayton, W. (2002). The Citizen Sector: becoming as Entrepreneurial and Competitive as Business California Management Review, 44(3). 120-132.

Ebimobowei, A. (2010). The Relationship between Fiscal Policy and Economic Growth in Nigeria (1991-2005). International Journal of Economic Development Research and Investment. Vol. 1 No.2 3 pp. 37 - 47.

Etim, E. O. (2010). Promoting Small and Medium Scale Enterprises in Nigeria: A Panacea for Realization of Financial Systems Strategy (FSS) 20:20:20. International Journal of Economic Development Research and Investment Vol. 1 No. 2 \& 3.

Fukuyama, F. (1995). Trust. The Social Virtues and the Creation of Prosperity, Hamish Hamilton, Londons.

Granovette, M. (1985). "Economic Action and Social Structure: The Problem of Embeddedness". American Journal of Sociology. Vol. 91(3) pp. 481-510.

Khorravi, A. and A. Karimi (2010). "Transition and Challenges of Rural Development in Nigeria" in B. Onuoha and M. Fadakinte (eds), Transition Politics in Nigeria, Malthouse Press Ltd. Lagos.

Khosravi, A. and Karimi, M.S. (2010). To Investigate the Relationship Between Monetary Policy, Fiscal Policy and Economic Growth in Iran: Autoregressive Distributed lag Approach to Co-Integration.

National Bureau of Statistical (NBS) (2012) Reports, Abuja, Nigeria.

Ndiyo, N. A. (2010). Poverty to Sustainable Development (A Community Based Approach). Calabar, University of Calabar Printing Press.

Obadan, M. J. (1997). "Analytical Framework for Poverty Reduction, Strategies and Programmes". NCEMA Analysis Series, Vol.2 (2).

Ogwumike, F. O. (1998). "The Effects of Macro-level Government Policies on Rural Developmental and Poverty Alleviation in Nigeria" Ibadan Journal of the Social Sciences, Vol. 1, No.1, pp. 85-101.

Onodugo, V. (2013). Realizing Vision 20:20:20 Economic Strategic Plan Through Benchmarking. A Paper Presented at ICAN - 8th Eastern Districts Conference, Uyo, AKS.

Udechukwu, F. N. (2009). CBN Seminar on Small and Medium Industries Equity Investment Scheme (SMIEIS). Lagos: CBN Training Centre.

World Bank (1995. Advancing Social Development. The International Bank for Reconstruction and Development, Washington D. C.

World Bank (1996) Various Issues. World Development Report, Washington D. C. 